\title{
Eylem Alanlarının Tanımlanması ve İşlevsellik Bağlamında Z-Kütüphanelerin İrdelenmesi
}

\author{
Didem ERTEN BiLGiĻ ${ }^{1 *}$, Nur Efşan GÖRECi ${ }^{2}$ (D) \\ ORCID 1: 0000-0002-6304-8648 \\ ORCID 2: 0000-0003-1424-9766 \\ ${ }^{1}$ Kocaeli Üniversitesi, Mimarlık ve Tasarım Fakültesi, İç Mimarlık Ana Sanat Dalı, 41300, Kocaeli, Türkiye. \\ ${ }^{2}$ Kocaeli Üniversitesi, Sosyal Bilimler Enstitüsü, Iç Mimarlık Ana Sanat Dalı, 41380, İstanbul, Türkiye. \\ *e-mail: didemerten@gmail.com
}

Öz

İ̧̧erisinde bulunulan bilgi çağında bir ülkenin gelişimi yeni nesillerin eğitimine gösterilen özenle şekillendirilmekte ve Covid-19 Pandemisinin gündelik yaşama getirileri ile yoğrulmaktadır. Bu bağlamda okul kütüphaneleri modern çağın getirilerine göre yenilenmeli, öğrencilere ihtiyaçları olan ortamı sunmaya hazır olmalıdır. Türkiye'de okul kütüphanelerini çağa uydurmak, yeni elektronik bilgi kaynaklarını eğitim sisteminde kullanabilmek adına Millî Eğitim Bakanlığı 2011 yılında Zenginleştirilmiş Kütüphane (Z-kütüphane) Projesi için çalışmalara başlamıştır. Bu çalışmanın konu aldığı proje kapsamında Z-kütüphanelerde eylem alanlarının tanımlanması ve bu bağlamda mekanların işlevsellik açısından ergonomik yeterliliklerinin incelenmesi amaçlanmıştır. Araştırma, ortaokullarda kurulan z-kütüphaneler üzerinde ilerlemiştir. Literatür taraması yapılarak eylem alanları belirlenmiş, daha sonra betimsel yöntem kullanılarak MEB'in yüklenici firmalara örnek olarak verdiği modeller üzerinden mekanların işlevselliği incelenmiştir. Sonuç olarak örnek olarak yol gösterici olması beklenen bu modellerde işlevselliği etkileyen hatalar tespit edilmiştir.

Anahtar Kelimeler: Mekansal organizasyon, mobilya, okul kütüphanesi, ortaokul, Z-kütüphane

\section{Defining Action Areas and Scrutinazation of E-Libraries in the Context of Functionality}

\begin{abstract}
In the present knowledge era, the development of a country is shaped by supporting better education for new generations and is reforged by the daily bringing of the Covid-19 Pandemic. To this extent, school libraries are ought to be modernized. To be able to use the new online knowledge sources in educational platforms, The Ministry of National Education (MNE) has initiated the Enriched Library (E-library) Project. This study aims to identify the action areas of E-libraries and investigate the ergonomic adequateness in terms of the functionality of their space within the context of the subject project. The research has progressed upon E-libraries established in middle schools. Action areas have been determined by literature review, using descriptive methods the functionality of space has been investigated through exemplar models which MNE provided for contractor companies. Consequently, in these models, expected to be used as guides, mistakes that alter functionality have been fixed.
\end{abstract}

Keywords: Spatial organization, furniture, school library, middle school, E-library

Citation/Atıf: Erten Bilgiç, D. and Göreci, N.E. (2021). Eylem alanlarının tanımlanması ve işlevsellik bağlamında zkütüphanelerin irdelenmesi. Journal of Architectural Sciences and Applications, 6 (2), 461-475.

DOI: https://doi.org/10.30785/mbud.944773 


\section{Giriş}

Ülkelerin gelişimi ekonomiyle paralel kültürel ve entelektüel bir gelişimin sağlanmasıyla hızlanmaktadır. Bu kültürel ve entelektüel gelişimi sağlamak ise toplumun, en başta yeni nesillerin eğitimine gösterilen özenle mümkündür. Bilgi çağının getirisi olarak öğrencilere hayat boyu öğrenme yeteneği kazandırmak, bilginin önemini kavratmak, bilgiye ulaşım yolları ve metotlarını öğretmek eğitim sisteminin bir parçasıdır. Bu amaçlar doğrultusunda okul kütüphaneleri bilgiyi öğrenmek, yorumlamak, kullanmak ve paylaşmak konusunda önemli yol, metot ve ortamlardan biridir. Eğitim sistemi öğrencileri kütüphane kullanımına teşvik etmeli, okul kütüphaneleri de öğrencilere yeterli donanım, kaynak, personel ve mekânı sunmak konusunda her zaman hazır olmalıdır.

Değişen dünya düzeni, teknolojik gelişmeler, gençlerin farklı istek ve idealleri bilgi çağını şekillendirmiş; bilgiye ulaşmada kullanılan yöntem ve metotlarındaki gelişmeler elektronik bilgi kaynaklarını ortaya çıkarmıştır. Bu değişim bilgiye ulaşmada kullanılan yollardan biri olan kütüphaneleri çağın yeniliklerine uyum sağlamak konusunda etkilemiştir. Kütüphane yapıları modern bilgi çağının gerisinde kalmamak, bilgiye ulaşımda sürdürülebilirliği sağlamak için; kaynaklarını, metotlarını, donanımlarını güncelleme çalışmalarına başlamıştır (Önal, 2015). Covid 19 pandemisinin etkilerinden biri olan dijital eğitim sistemlerinin gündelik hayatımızda daha çok yer alması ile okul kütüphanelerinin de içeriklerinin yeniden gözden geçirilmesi gerekliliği ortaya çıkmıştır. Okul kütüphaneleri öğrencilerin dijital sistemleri benimsemeleri açısından destekleyici içerikler ortaya koymalıdır.

Türkiye'de de Millî Eğitim Bakanlığı elektronik bilgi kaynaklarının kullanımını sağlamak, öğrencilerin bilgiye ulaşım yollarında desteklemek amacıyla 2011 yılında "Z-Kütüphane (zenginleştirilmiş kütüphane) Projesi" için çalışmalara başlamıştır. 2015' de yapılan "Okuma Kültürü ve Z-Kütüphane Çalıştayı" Sonuç Raporuna göre Z-Kütüphaneler; bilgi çağının taleplerine göre sesli ve elektronik kitap kaynaklarına ulaşılabilen; öğrencilerin okuma, araştırma, ders çalışma gibi eylemlerin yanı sıra yapboz ve satranç gibi zekâ oyunlarıyla eğlenirken geliştikleri; pedagojik açıdan uygun renklerle düzenlenmiş, estetik ve ilgi uyandıran bir ortam olarak öğrencileri kütüphane kullanmaya teşvik eden bir kütüphane mekanıdır. Bu proje sayesinde ilgi uyandırmaktan uzak, geri planda kalmış klasik okul kütüphanelerinden uzaklaşarak, yeni ve çağın getirilerine uygun, öğrencilere keyifli vakit getirisi olan Z-Kütüphaneler tasarlanmıştır.

Z-Kütüphaneler öğrencilerin okuma, araştırma, ders çalışma gibi eylemleri yapmanın yanında; arkadaşlarıyla çalışabilecekleri, oyun oynayabilecekleri, sınıfça okuma günleri gibi etkinliklerin yapıldığı, akıllı tahta kullanımın olduğu hem eğitim hem de sosyalleşme alanlarıdır. Bu sebeple mekân organizasyonu ve ergonomik koşulların sağlanması kütüphane kullanıcıları olan öğrencilerin, kütüphanecinin, öğretmenlerin, velilerin, okul yönetiminin ve diğer personellerin kütüphaneyi verimli ve etkin kullanması açısından önemlidir.

\section{Materyal ve Yöntem}

MEB tarafından 2019 yılında hazırlanan "Zenginleştirilmiş Kütüphane (Z-Kütüphane) Kurulumu ve Donatımına iliş̧kin Teknik Şartname" ye göre okulun giriş katında; ilkokullar için en az 60 en fazla 70 $\mathrm{m} 2$, ortaokullar için en az 70 en fazla $80 \mathrm{~m} 2$, liselerde ise en az 80 en fazla $100 \mathrm{~m} 2$ alan yeterliliğine sahip okullarda z-kütüphane kurulumu yapılmaktadır. Eğitimde fırsat eşitliği hakkı ve On Birinci Kalkınma Planı'nın (2019-2023) eğitim kategorisi politika ve tedbirler başlığı altındaki 550.maddede yer alan "Tüm eğitim kademelerinde okulların niteliği ve imkanları arttırılarak okullar arası başarı farkı azaltılacaktır." söylemi bu şartların yeniden gözden geçirilmesi ve iç mimari çözüm yolları sunulması gerekliliğini ortaya koymaktadır (Türkiye Cumhuriyeti Cumhurbaşkanlığı Strateji ve Bütçe Başkanlığı, 2019).

Bu çalışmanın amacı; çoklu eylem alanlarına sahip olan Z-Kütüphanelerde eylem alanlarının tanımlanması ve bu eylem alanlarının işlevsellik bağlamında incelenerek yeterliliklerini ve eksikliklerini ortaya koymaktır. Araştırma ortaokullar üzerinden ilerlemiștir. Bu kapsamda iki aşamalı bir yöntem izlenmiştir. Illk aşamada yüklenici firmalarla iletişime geçilip gerekli bilgi ve belgeler edinilmiş, "Okul Kütüphaneleri Yönetmeliği ve Z-Kütüphane Çalıstay Raporu" esas alınarak z-kütüphanelerde gerekli eylem alanları belirlenmiştir. Bu bilgiler doğrultusunda ve Covid-19 pandemisi sebebiyle yerinde 
inceleme yapılamadığı için Millî Eğitim Bakanlığı'nın kullanılmasını tavsiye ettiği modellerin detaylarının izlenebildiği üç adet örnek model üzerinden eylem alanları tanımlaması yapılmıştır (Millî Eğitim Bakanlığı Z Kütüphane, 2019). Yüklenici bir firma ile iletişime geçilerek konu hakkında detaylı bilgiler derlenmişsir (Ö. Canbolat, kişisel iletişim 04.05.2021). íkinci aşamada ortaokul öğrencilerinin yaş grubu, fiziksel ve zihinsel gelişimleri, kütüphane kullanıcılarının boyutları hakkında literatür araştırması yapılarak MEB'in paylaştığı örnek Z-Kütüphane görselleri üzerinden betimsel yöntem kullanılarak bu mekanların işlevsellik açısından incelemesi yapılmıştır.

Sonuç olarak MEB'in yüklenici firmaların yapacağı Z-kütüphane tasarımları için örnek olarak sunulan modellerin işlevsellik yönünden hatalarının olduğu tespit edilmiş, bu hataların düzeltilmesi gerekliliği ortaya konmuştur.

\section{Araştırma Bulguları}

\subsection{Z-Kütüphane Tanımı ve İçeriği}

Z-Kütüphane; estetik ve ergonomik tasarımıyla öğrencilerin okullarda bilgiyi sevme, öğrenme ve dinlenme etkinliklerine imkân veren sosyal etkinlik alanıdır. Z-Kütüphaneler planlanırken bilgiye erişimde fırsat eşitliği sağlayan, sesli ve elektronik kitaplar içeren, modern ve estetik bir tasarıma sahip, pedagojik uygunluk sağlanmış, taşınabilir raflar bulunduran, ahşap ve kumaşla kaplı duvarları olan, okuma zevki uyandıran bir ortam olması amaçlanmıştır. Tadilat ve altyapı, mobilya, bilgisayar, yazıcı ve kitap z-kütüphaneleri oluşturan bileşenlerdir (Millî Eğitim Bakanlığı Z Kütüphane-a, t.y.).

Öğrencilere bilgiye ulaşım yöntemlerini öğretme, bilgi edinme, bilgiyi kullanma ve paylaşma, yaratıcılığı arttırma, hayat boyu öğrenme yeteneği kazandırma amacıyla gerekli ortamı sağlamak; sosyal ve kültürel gelişimin öneminin vurgulanarak bu gelişimleri sağlamak amacıyla etkinlikler, özel günler düzenlenmesi; öğrencilere bilgiye erişimde özgürlüğün gerekliliğinin benimsetilmesi; ülkemiz için hedeflenen ekonomik kalkınma ile beraber kültürel bir kalkınma da sağlanması için entelektüel sermayeye yatırım yapmak amacıyla z-kütüphanelerden faydalanılmak istenmiştir.

Z-Kütüphane kurulumu; şartları sağlayan okullar için ihale açılması ve bu ihaleyi alan yüklenici firmaların şartnameye uygun olarak elektrik tesisatı, bakanlığın yayınladığı örnek z-kütüphane görselleri üzerinden iç mimari tasarım ve uygulama, kitap ve bilgisayar gibi gerekli donanımın sağlanması gibi tüm kurulum aşamalarını yerine getirmesiyle gerçekleşmektedir.

Ocak 2019'da 6.versiyonu yayınlanan "Z-Kütüphane Teknik Şartnamesi”nde z-kütüphane için yeterlilik şartları, gerekli tadilat ve tamirat, mobilya ve tefriş, elektrik ve internet altyapısı, bilgisayar ve yazıcı, kitap seçimi ve teminine ilişkin bilgiler yer almaktadır. Bu maddelerden bazıları fazlasıyla açıkken bazı maddeler net bir şekilde amacını ortaya koyamamıştır (Millî Eğitim Bakanlığı Z Kütüphane, 2019).

2014'te z-kütüphane kurulumlarının başlamasıyla projenin geliştirilmesi ve veriminin arttırılması amacıyla 2015'de Z-Kütüphaneler hakkında çalıştay yapılmış, ülkemizden ve başka ülkelerden katılımcılar dinlenerek, incelemeler yapılarak bir rapor hazırlanmıştır. Bu raporda iç mekân tasarımı ile ilişkili olarak özetle;

- Öğrencilerin \%25,7'sinin z-kütüphaneleri dinlenme amacıyla kullandığı belirlenmiş, buna göre ortamın daha cazip hale gelmesi amacıyla yararlı dinlenme gibi konseptler geliştirilmelidir,

- Öğrencilerin $1 / 5^{\prime}$ inin arkadaş etkisiyle kütüphane kullanmaktadır, bu yüzden kütüphanelerin sosyalleşme amacına da hizmet etmek adına grup aktivitelerine ve birlikte ders çalışma imkanına olanak tanımalıdır,

- Yeni yapılan z-kütüphaneler engelli dostu biçiminde tasarlanması sağlanmalıdır,

- Lise seviyesindeki öğrencilerin \%36,6'sı z-kütüphanelerin renklerini ve tasarımını beğenmediği, buna göre lise seviyesindeki okullara yapılan z-kütüphanelerin tasarımında iç mimar ve dekorasyon uzmanları ile iş birliği yapılması gerekmektedir,

- Gelecekte büyütülmesi gerekirse daha az maliyetle bu büyümeyi sağlayacak biçimde tasarlanmalı ve planlanmalıdır, önerilerinde bulunulmuştur (MEB Destek Hizmetleri Genel Müdürlüğü Eğitim Araçları ve Yayımlar Daire Başkanlığı, 2015). 
Bu veriler ve iletişime geçilen yüklenici firmalardan alınan bilgiler doğrultusunda z-kütüphane tasarım aşamasında iç mimarlar ile çalışılmadığı tespit edilmiş, mesleki sorumluluk gereği mekân tasarımının ilk aşaması olan eylem alanları belirlenmiştir.

\subsection{Z-Kütüphanede Eylem Alanlarının Belirlenmesi}

Z-Kütüphaneler okuma, araştırma ve ödev yapma gibi temel eylemlerin yanı sıra yapboz, satranç gibi zekâ oyunları oynama, akıllı tahtayı kullanma, imza etkinlikleri düzenleme, özel günleri kutlama, film izleme, bilgisayar üzerinden ödev ve araştırma yapma, sınıfça ders işleme, rahat koltuklarda arkadaşlarıyla birlikte vakit geçirme gibi öğrencilerin sosyalleşmesine ve eğlenmesine imkân sağlayan eylem alanlarını içinde barındırmaktadır. Ayrıca kütüphane kullanıcılarından biri olan kütüphaneciler için çalışmasına ve kütüphaneyi gözetlemesine olanak sağlayan, fotokopi, tarayıcı gibi donatıları kullanmaya imkân veren eylem alanlarını da içermelidir. Bu bağlamda ofis alanı, grup alanları, dijital alan ve sessiz alan olarak eylem alanları tanımlanmış ve Çizelge 1'de gerekli açıklamalar yapılmıştır.

Çizelge 1. Z-Kütüphanede temel eylem alanları (MEB Destek Hizmetleri Genel Müdürlüğü Eğitim Araçları ve Yayımlar Daire Başkanlığı, 2015 kaynağından makale için yeniden düzenlenmiştir.)

\begin{tabular}{|c|c|}
\hline Bireysel Okuma ve Çalışma Alanı & $\begin{array}{l}\text { Öğrencilerin tek başına kitap okuma, ödev yapma, araştırma } \\
\text { yapma, yapboz oynama gibi eylemleri gerçekleştirmesine imkân } \\
\text { veren alandır. }\end{array}$ \\
\hline Rahat Okuma Alanı & $\begin{array}{l}\text { Öğrencilerin rahat koltuk ve puflar aracılığıyla, rahatsız } \\
\text { edilmeden ve dikkatin dağılmasına sebep olunmadan okuma } \\
\text { yapmasına imkân veren alandır. }\end{array}$ \\
\hline Bilgisayar Alanı & $\begin{array}{l}\text { Öğrencilerin bilgisayar aracılığıyla ödev, araştırma yapması, } \\
\text { görsel bilgi kaynaklarını kullanması, film izlemesi gibi eylemlere } \\
\text { imkân veren alandır. }\end{array}$ \\
\hline Eğitim Alanı & $\begin{array}{l}\text { Akıllı tahtayı içinde bulunduran sınıf sunumlarına, özel } \\
\text { etkinliklere, film günlerine imkân veren alandır. }\end{array}$ \\
\hline Grup Çalışma Alanı & $\begin{array}{l}\text { Öğrencilerin arkadaşları ile birlikte ödev, araştırma yapmasına, } \\
\text { grup etkinliklerine imkân veren alandır. Mekânda özel bir alan } \\
\text { ayarlanabileceği gibi ihtiyaç halinde basit bir dönüşümle de } \\
\text { ulaşılabilen bir alan olabilmektedir. }\end{array}$ \\
\hline Satranç Alanı & $\begin{array}{l}\text { Öğrencilerin zekâ geliştirici satranç oyunu oynamasına olanak } \\
\text { veren özel satranç masasına sahip alandır. }\end{array}$ \\
\hline Görevli Çalışma Alanı & $\begin{array}{l}\text { Kütüphanecinin kullanımına ait, kütüphaneyi gözetlemesine } \\
\text { imkân veren, işitsel ve görsel kaynakları içinde bulunduran, } \\
\text { kütüphaneci-öğretmen ortak eylemlerinde kullanılmak üzere } \\
\text { düzenlenmişalandır. }\end{array}$ \\
\hline $\begin{array}{l}\text { Danışma/Ödünç Alma Alanı/Yardım } \\
\text { Masası }\end{array}$ & $\begin{array}{l}\text { Öğrencilerin aradığı kitapları bulmak üzere bilgi edinmesini } \\
\text { sağlayan yardım masasını içeren, fotokopi-tarayıcı gibi cihazları } \\
\text { kullanmaya olanak sağlamak üzere düzenlenmiş alandır. }\end{array}$ \\
\hline Depo & $\begin{array}{l}\text { Kütüphane materyallerinin saklandığı alandır. Özel olarak } \\
\text { ayrılacağı gibi görevli çalışma alanının içinde de düzenlenebilir. }\end{array}$ \\
\hline
\end{tabular}

\subsection{Eylem Alanlarının İşlevsellik Açısından Ergonomik Yeterlilikleri}

Hasol (2020), işlevi "kullanılış veya işleyiş bakımından maksada uygunluk, belirli bir maksatla ilgili eylem türü ya da amacı gerçekleştiren eylem tarzı; uğruna belirli bir şeyin yapıldığı görev, fonksiyon" olarak; işlevselliği ise "kullanış ya da işleyiş bakımından maksadına uygun olan" şeklinde tanımlamıştır. Buna göre herhangi bir mekânın bölümleri hem kendi aralarında hem de birbirleriyle olan ilişkileri bakımından incelendiğinde, içlerinde yaşayan ya da çalışan kullanıcısının eylemlerini kusursuz ve kolayca yapmasını sağlayan tarzda düzenlenmişse o mekânın fonksiyonel olduğunu söylemektedir.

Mekanların kullanılabilir olması için amacına uygun bir şekilde tasarlanmış olması gerekmektedir. Bu nedenle işlevsellik ön plana çıkmaktadır. Mekân içerisindeki işlevsel gereklilikler:

- Tefrişin işlevsel olarak gruplandırılması ve yerleştirilmesi,

- Uygun boyutlar ve ara mesafeler,

- Uygun sosyal mesafeler,

- Uygun görsel ve akustik mahremiyet, 
- Yeterli derecede esneklik ve uyum yeteneği,

- Uygun aydınlatma ve diğer elektriksel, mekanik servisler olarak belirlenmiştir.

Aynı zamanda mekânın estetik işlevi de bulunmalıdır. Estetik bir yapının, mekânın veya mobilyanın göze hoş görünür niteliklerini sergilemesi ve üzerine yüklenmiş olan görevlerini karşılamasıdır. Estetik işlevi sağlamak; uygun ölçekler kullanma, görsel gruplandırmalar oluşturma, ritim, uyum, denge sağlama, ışığa, manzaraya ya da bir odak noktasına doğru yönelme ve biçim, renk, doku, desen kullanımı ile sağlanmaktadır (Bayram, 2011).

Okul kütüphanesi olarak Z-kütüphanelerin oluşturulmasında okul kütüphanesi yönetmeliklerinden faydalanılmıştır. Okul kütüphanelerinde işlevselliğin sağlanması birçok yönetmelik ve bildiride kontrol altına alınmıştır. IFLA/UNESCO'nun hazırladığı okul kütüphanesi rehberine göre okul kütüphaneleri (IFLA Okul Kütüphaneleri Bölümü Daimî Komitesi, 2002);

- Kütüphanenin en az bir bölümünün dışarıdan gelen gürültüye karşı korunması,

- Hem pencereden hem de aydınlatma yöntemiyle uygun ve yeterli derecede aydınlık sağlanması,

- Yıl boyunca olabilecek hava değişimine bağlı olarak çalışma odalarının ve koleksiyonun korunduğu alanların nem, sıcaklık/soğukluk derecesinin uygun hale getirilmesi,

- Özel gereksinimlerle karşılayabilecek engelli kütüphane kullanıcılarına yönelik uygun tasarım yapılması,

- Roman, bilimsel, ciltli ve karton kapaklı kitaplar, gazeteler ve dergiler, basılı olmayan kaynaklar, depo, çalışma ve okuma alanları, bilgisayarla çalışma yerleri, sergi alanları, görevli çalışma alanları ve bir yardım masası için yeterli boyutta yer sağlanması,

- Müfredatta ve teknolojide gelecekte olabilecek değişikler hakkında ve etkinlikler konusunda çeşitlilik sağlamak için esnek bir yapıya sahip olması gerekmektedir.

Ayrıca estetik görünümün çalışanlara ve öğrencilere kütüphaneyi kullanma arzusu sağladığını belirtilerek doğru şekilde düzenlenmiş bir okul kütüphanesinin aşağıdaki şartları sağlamış olması gerektiği ifade edilmiştir:

- Güvenli bir ortam,

- İyi bir aydınlatma sistemi,

- Kütüphanenin özel alan, etkinlik ve okuyucu gereksinimlerini karşılamada olduğu gibi kütüphane içerisinde kullanılacak mobilyanın da sağlam, uzun ömürlü ve işlevsel olacak şekilde tasarlanması,

- Kütüphanenin kullanıcıların özel isteklerini azami derecede karşılayacak şekilde tasarlanması,

- Kütüphanenin, işitsel, video ve veri teknolojisinde ortaya çıkan gelişmelerde olduğu gibi kütüphane ve okulun eğitim öğretim programında ortaya çıkan değişiklikleri de karşılayacak şekilde tasarlanması,

- Mobilya, donanım, sarf malzemesi ve materyallerin uygun ve güvenli kullanımına, bakımına olanak sağlayacak şekilde tasarım yapılması,

- Düzenlemesi yapılmış farklı koleksiyondaki kaynakların eşit bir şekilde ve zamanında erişimini sağlamaya yönelik karar alınması ve yönetilmesi,

- Okunaklı, göz alııı rehber ve yol gösterici levhalarla, estetik olarak okuyucuya hitap eden, hoşça vakit geçirmeye ve örenmeye yardım edecek şekilde düzenlenmesi ve yönetilmesi (Gürbüz, 2013).

Okul Kütüphanecileri Derneği'nin paylaştığı fiziki ilke ve standartlara göre kütüphanede ısıtmasoğutma-havalandırma sistemi, nem dengesi, uygun ortam sıcaklığı ve ses yalıtımı olmalıdır. Kütüphane engelli ihtiyaçlarına uygun bir şekilde tasarlanmalıdır. Farklı materyal türleri ve ekipmanlar için uygun 
alanlar ayrılmalı, tüm alanlar yeterli büyüklükte olmalıdır. Kütüphanede küçük ve büyük çalışma grupları ve sınıfın tamamına verilecek eğitimler için uygun teknoloji içeren alanlar bulunmalıdır. İç mekân çeşitli etkinlikler için yer değişikliğine izin verecek esneklikte olmalıdır. Kütüphane, kullanıcıların psikolojik yapısı üzerinde olumlu etki yaratacak estetik biçimde tasarlanmalıdır (Okul Kütüphanecileri Derneği, t.y).

Kütüphanelerin işlevini yerine getirmesinde renk etkileri önemlidir. Sıcak bir kütüphane ortamının oluşturulması öğrencilerin ilgisini çekerek okumaya, eğlenmeye, bilgi edinmeye, araştırmaya teşvik etmelidir. Orta okul öğrencileri için aydın ve neşe dolu bir kütüphane ortamına gereksinim duyulmaktadır. Mekânda kullanılan renkler çocukluk heyecanını yansıtan parlak, ana renkler olmalıdır (Hashempour, 2015). Okul kütüphanelerinde raflar, kitaplar, döşeme, poster, tabela, duvar, halı renk etkisini sağlamada etkili yüzeylerdir. Sağ beyni aktif olarak kullanan öğrencilerde renk duyarlılığı vardır. Bu sebeple kütüphanede kitapların renk kodlu olması bu öğrencilerin aramasını kolaylaştırmaktadır (Miner94, 2009).

Orta okullar 10-14 yaş dönemini kapsamaktadır. 10-11 yaş çocukluğun sonuna denk gelmekte, öğrenciler bu dönemde bir yandan büyümek bir yandan çocuk kalmak istemektedir. Bu yaş grubundaki öğrenciler haritalara, eğitici oyunlara, grup çalışmasına ve konuşma yapmaya ilgi duymaktadırlar (Doğan,2007). Ayrıca meraklı, hareketli ve konuşkan olan bu yaş grubu dolaşma, kapı çarpma ve bunlar gibi gürültü oluşturucu davranışlarda bulunurlar. Hareketlilik çok fazladır (Baran, 2011). 12-14 yaş arası ise ergenlik dönemine denk gelmektedir (Doğan,2007). Bu dönemde bedensel gelişme hareketleri de etkilemektedir. Kemik ve kaslardaki büyüme hızlarının farklı olması motor becerileri etkilemekte ve öğrenciler vücut koordinasyonunu sağlamada zorluk yaşamaktadır (Baran, 2011). Buna göre kütüphanelerde kullanılan mobilyalar güvenli bir ortam koşulunu sağlaması amacıyla öğrencilerin hareketliliği düşünülerek tasarlanmalıdır. Mobilya köşeleri ovalleştirilmiş olmalı, mobilyalar sabitlenmeli ya da öğrencilerin kendi başına hareket ettirmesinin önlenmesi amacıyla kilitlenebilir olmalıdır. Devrilmeleri önlemek adına mobilyaların en, boy, genişlik oranları dikkate alınmalıdır. Raflar güvenlik problemi yaratmayacak şekilde yerleştirilmelidir. Ortaokullar için raf yükseklikleri $120-150 \mathrm{~cm}$ arasında olmalıdır. Her bölmede en az bir adet ön yüzü görülebilen raflar olmalıdır. Çocukların yaş grubuna uygun boyutta masa ve sandalyeler bulundurulmalıdır. Rahatlık, hijyen ve kullanıma uygunluk ilkelerinin gözetildiği halı, perde gibi donatılar tercih edilmelidir (Okul Kütüphanecileri Derneği, t.y.).

Okul kütüphanelerine erişimin ve iç mekânın bedensel engellilerin kullanımına uygun olması gerekmektedir. Okuma alanları düzenlenirken gün ışığından yararlanacak şekilde olmasına dikkat edilmeli, yapay aydınlatma 500 lüks oranında ışıklandırma sağlamalıdır. Gün ışı̆̆ının doğrudan kitaplara vurarak zarar vermesi engellenmelidir. Kütüphane içerisinde ulaşım yolu genişlikleri $120 \mathrm{~cm}$ 'den, raflar arası mesafe 130-140 cm'den büyük olmalıdır (Küçükcan,2015).

Kütüphanede farklı eylem alanlarının bulunması farklı ihtiyaçları da beraberinde getirmektedir. Buna göre incelemeler z-kütüphanelerde belirlenmiş dört ana eylem alanı üzerinden ilerlemiştir.

\subsubsection{Sessiz alan}

Sessiz alanlar okuma, araştırma yapma, ders çalışma gibi eylemlere yönelik tasarlandığından kütüphanede gürültüye karşı korumanın en gerekli olduğu eylem alanıdır. Bu ses düzeyinin düşük olduğu ortam, sessiz alanı kütüphanenin kalanından hareketsiz bölücülerle ayırarak sağlanabileceği gibi, mekân içinde yapılan akustik düzenlemelerle de gerçekleştirilmektedir. Bu akustik düzenlemeler sessiz alanın mekân içinde konumlandırılması, malzeme seçimi ve sesin yayılımını engelleyecek donatıların yerleştirilmesi ile alakalı düzenlemelerdir.

Sessiz alanlar mekân içinde giriş gibi hareketliliğin, gürültünün ve dikkat dağıtıcı unsurların yoğun olduğu bölgelerde konumlandırımamalıdır. Daha izole bölgeler tercih edilmeli, mekân içindeki sirkülasyondan etkilenmemelidir. Kütüphane içinde uygun şartların sağlandığı alanlara entegre edilebilir olmalıdır. Komşu eylem alanlarıyla ilişkisi, amaçlanan odaklanma ortamı göz önüne alınarak sağlanmalıdır.

Sessiz alanda işleve yönelik mobilya gereksinimleri kitap sergileme birimleri, çalışma masaları ve sandalyeleri, rahat koltuklar ve farklı şekillerdeki puflardır. Çalışmanın sınırlııkları dahilinde incelenen 
ortaokullarda, öğrencilerin lise sınavlarına hazırlanma dönemi olduğu için tek kişilik, görsel mahremiyetin sağlandığı çalışma birimleri de düşünülmelidir. Zeminden kaynaklı seslerin önlenmesi için, hijyen koşulları göz ardı edilmeden, halı kullanımı tercih edilebilir.

Okuma eyleminin yoğun gerçekleştiği bir alan olması nedeniyle aydınlatmanın homojen olması gerekmektedir. Okuma ve çalışma yüzeylerine gölge düşümü engellenmelidir. Uygun malzeme seçimi ve aydınlatma düzeyi ile göz sağlığını kötü etkilemeyecek, parlamaya sebep olup gözde rahatsızlık yaratmayacak bir ortam oluşturulmalıdır.

Şekil 1'de gösterilen görselde Örnek Model 1'e ait sessiz alanın mekandaki konumu gösterilmiştir. Alanda rahat okuma için armut koltuklar ve puflar kullanılmıştır. 4 kişilik çalışma masaları kullanılmış, bireysel çalışmaya yönelik donatı seçimleri yapılmamıştır. Tek başına ders çalışmak isteyen bir öğrenci, kütüphanenin yoğun kullanıldığı zaman dilimlerinde masasını başka bir kullanıcı ile paylaşmak zorunda kalacak, bu da odaklanmada zorluklar yaşamasına sebep olacaktır. Aynı zamanda görsel mahremiyetin sağlandığı alanların olmaması kullanııının dikkatinin sık sık dağılmasına sebep olacaktır. Pufların bir kısmı kitaplık ve duvarla bitişik konumlandırılmış hem pufların kullanımı hem de kitaplığa erişim engellenmiştir. Ortaya yerleştirilen mantar desenli puflar, orta kitaplıklardan faydalanan kullanıcılara zorluk çıkarabilir, geçişe engel olabilir. Kütüphanenin sağ duvarında gemi konseptli bir kitaplık tasarımı görülmektedir. Eğlenceli tasarımı ile öğrencilerin ilgisini çekmesi sağlanmıştır. Bu tasarımda kitap raflarının bir kısmı kenarları yumuşatılmış bir şekilde üretilmişken bir kısmı köşeli bırakılmıştır. Köşeli kısımlar çarpma ihtimali yaratıp risk oluşturmaktadır.

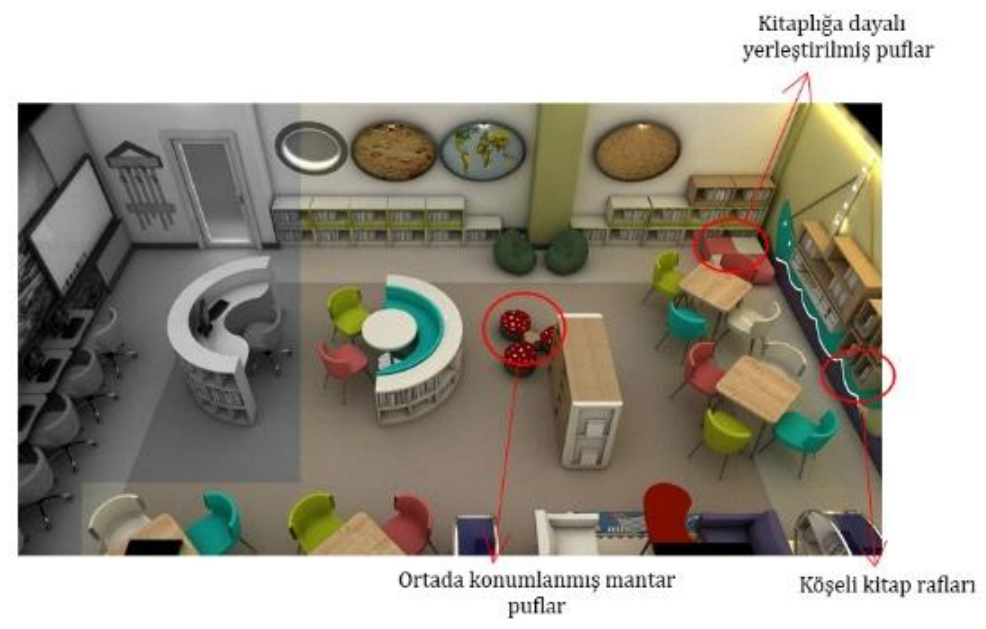

Şekil 1. Model-1 sessiz alanlardaki problemlerin tespiti

Örnek Model-2'de sessiz alanlarda birçok farklı rahat okuma birimi tasarımına yer verilmiştir. Yatay kitap sergileme ünitesi tasarlanarak etrafında puflar konumlandırılmış, öğrencilerin dinlenirken bir taraftan kitapları incelemelerine imkân verilmiştir. Yarım daire biçiminde iki adet mobilya birleştirilerek $S$ formu verilmiş, dışı kitaplık iç kısmı oturma birimi olarak düşünülmüş bir mobilya tasarımı kullanılmıştır. Köşede basamaklı bir platform oluşturarak minder ve puflar yerleştirilmiş, öğrenciler için rahat bir okuma alanı sağlanmıştır. Bu platformda ve mekânda bağımsız birçok noktada konumlandırılmış puflar, ihtiyaç halinde diğer alanlarda kullanılarak esnek kütüphane modelinin oluşturulmasına olanak vermektedir.

Model-2'de bireysel çalışma birimlerine yer verilmemiş hem bireysel hem grup çalışmalarına ortam sağlayan 4 kişilik masalar kullanılmıştır. Bu masalardan bazıları giriş alanı sirkülasyonunda konumlandırılmış, bu masalarda verimli çalışma durumu olumsuz etkilenmiştir. Duvarda konsol biçiminde kitaplık kullanılması, donatı yüksekliği ve tasarım içeriğindeki hatalar sebebi ile kullanıcılar için çarpma ve yaralanma riski oluşturmuştur.

Mekânda sessiz alanlarla bitişik satranç alanı, grup çalışma masaları, bilgisayar alanlarının olması, arada sesin yayılımını engelleyen donatıların da bulunmaması ile sessiz alanda gürültü seviyesini olumsuz etkileyip işitsel konforun bozulmasına sebep olabilir. Aydınlatma beş adet pencereden gelen doğal ışık ve tavanda aralıklarla yerleştirilen yapay aydınlatmalarla sağlanmaktadır. İstenmeyen ışı̆̆ın kontrolü zebra perde kullanımı ile kontrol altına alınmıştır. Aydınlatma da homojen bir dağıım sağlanamamış, 
karanlık alanlar oluşmuştur. Bu da öğrencinin okuma konforunu düşürür ve göz sağlığını olumsuz etkiler Şekil 2).
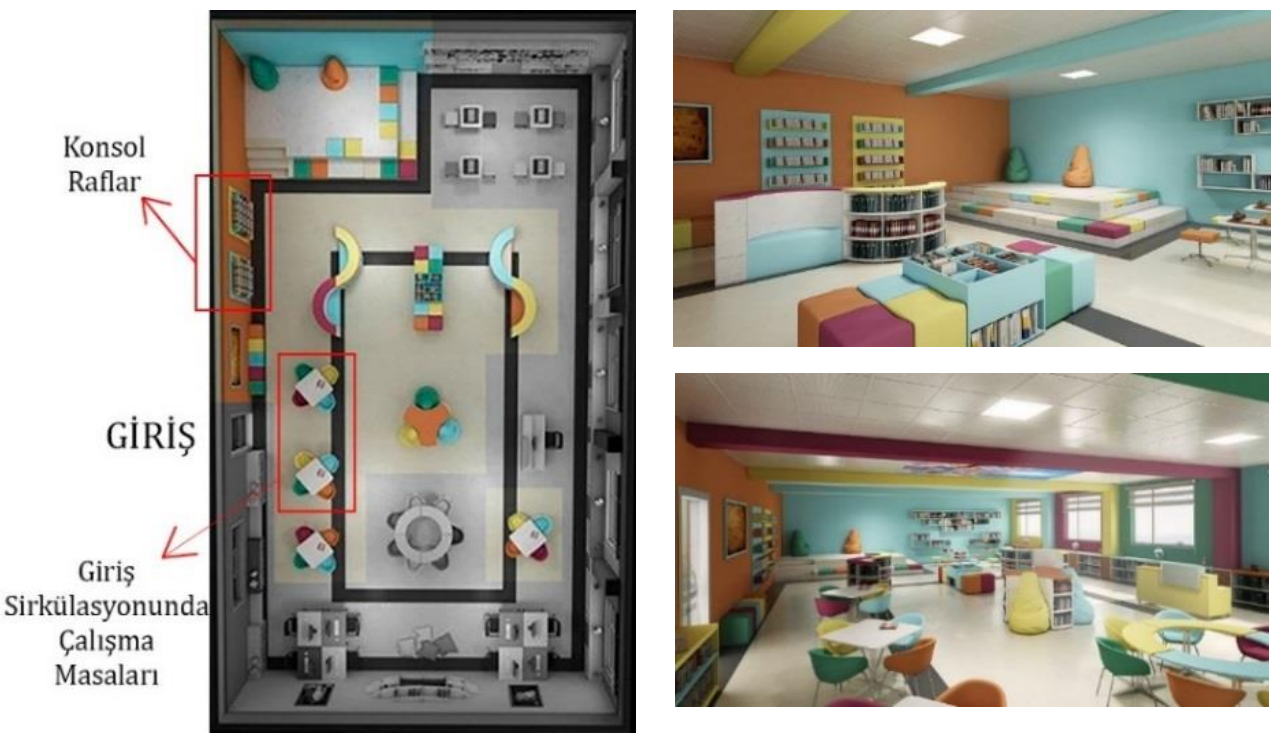

Şekil 2. Model 2'ye ait plan üzerinde sessiz alanların gösterimi ve görsel örnekleri (Görsel “Millî Eğitim Bakanlığı Z Kütüphane"-b kaynağından alınmış, 2. yazar tarafından düzenlenmiştir.)

Model-3'de basamaklı bir platforma yer verilmiş, rahat ve renkli yastıklarla dekore edilerek keyifli bir okuma köşesi sağlanmıştır. Fakat bu platformun yaslandığı duvarda konumlandırılan panolar erişilebilir olmaması sebebiyle işlevini yerine getirememektedir. Mekânda bağımsız noktalarda puf ve armut koltuk kullanılmıştır. Rahat koltuklardan bir okuma bölümü oluşturulmuştur. Bu bölüm bir kitaplık ünitesine bitişik yerleştirilmiş, kitaplığın işlevini kaybetmesine sebep olmuştur.

Bireysel çalışma alanlarına yer verilmemiş, 4 kişilik masalar tercih edilmiştir. Orta alanlarda bulunan kitaplıkların yere sabit olmadığı durumda, çocukların çarpma ve tırmanma davranışında bulunma intimallerine karşı, devrilme riski taşıdığı gözükmektedir. Duvara sabitlenen kitap rafları kullanılmıştır. Bu rafların yüksekliği öğrencilerin ulaşabileceği seviyeden yüksek kalmıştır.

Girişte bulunan dijital alan ile yan yana konumlandırılan okuma birimlerinde akustik konfor göz ardı edilmiştir. Aydınlatma 4 adet pencereden gelen doğal ışık ve tavanda bulunan gergi tavan ile sağlanmaktadır. Pencerelerde zebra perde kullanılarak doğal ışığın kontrolü sağlanmıştır. Sessiz alandaki duvarlarda İstiklal Marşı'na ve Çanakkale Savaşı'na ait görsellere yer verilmiştir (Şekil 3).
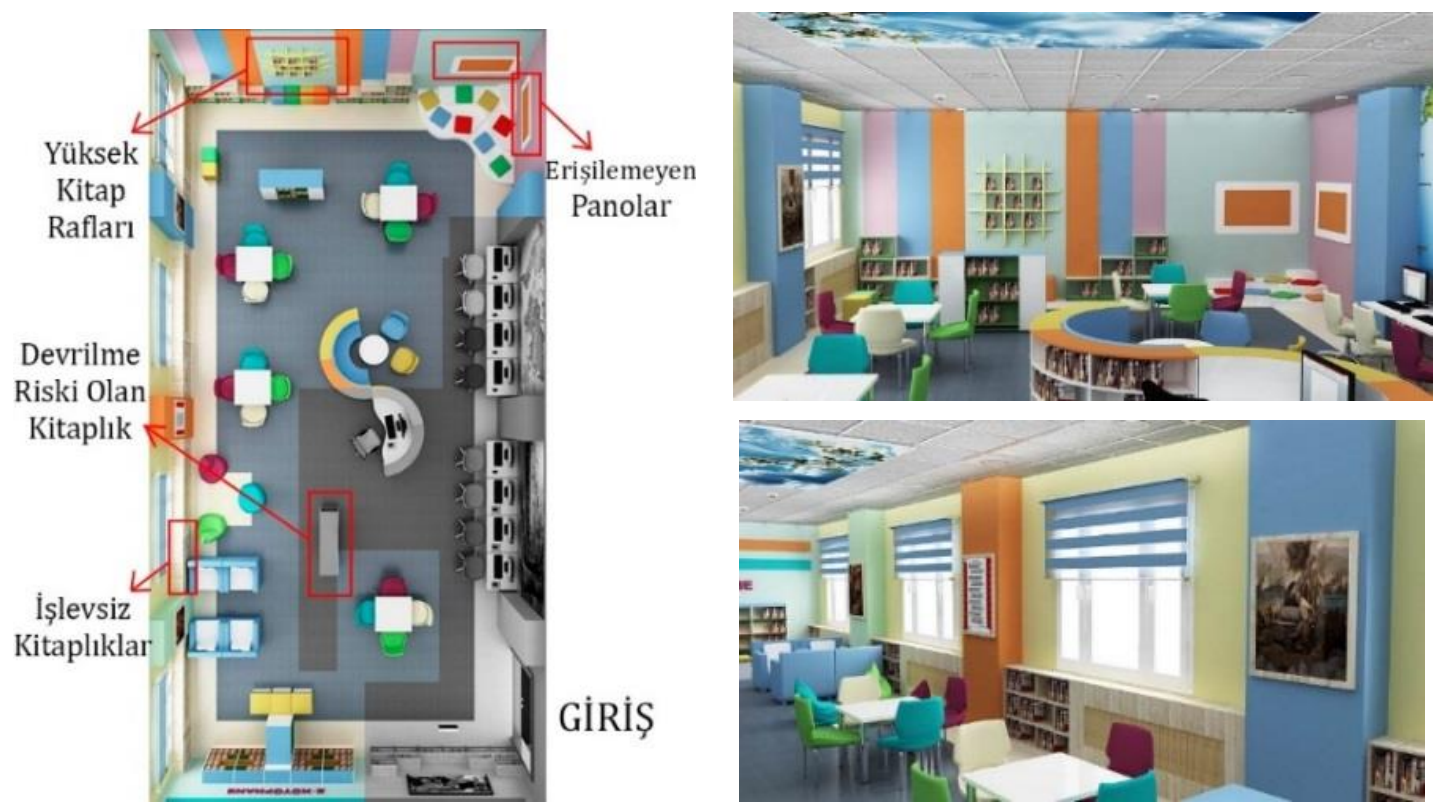

Şekil 3. Model 3’e ait plan üzerinde sessiz alanların gösterimi ve görsel örnekleri (Görsel “Millî Eğitim Bakanlığı Z Kütüphane"-b kaynağından alınmış, 2. yazar tarafından düzenlenmiştir.) 


\subsubsection{Dijital alan}

Dijital alan; araştırma, ödev yapma, film izleme gibi eylemlerin yapıldığı bilgisayar alanını ve içinde akıllı tahtayı bulunduran eğitim alanını kapsar. Dijital alanda işleve yönelik mobilya gereksinimi bilgisayar masaları, sandalyeleri, bilgisayar ve akılı tahta gibi dijital ekipmanlar ve akıllı tahta kullanımı anında organize edilebilecek sandalye ve çeşitli puflardır. Bilgisayar masaları öğrencilerin bilgisayarı kullanırken not almasına da imkân verecek genişliğe sahip olmalıdır. Engelli kullanıcılar ve farklı boy ölçüleri düşünülerek yüksekliği ayarlanabilir masalar olmalıdır. Bilgisayar sandalyeleri bedensel sağlığı korumak amacıyla ergonomik olmalıdır. Akıllı tahtanın önündeki mobilyalar hareketli olmalı, kalabalık etkinliklerde taşınarak alan genişletilmelidir. Fakat güvenlik ve mekân kontrolünü sağlamak açısından bu donatıların öğrencilerin hareket ettirmesine engel olunmalı, sadece kütüphane görevlisinin ya da öğretmenlerin kontrolünde hareketini sağlamak için tekerleklerinde kilit mekanizması olmalıdır.

Bu alanda aydınlatma armatürleri elektronik cihazların ekranlarında parlamaya sebep olabileceği için dikkatli tercih edilmelidir. Aynı zamanda kontrolsüz ışı gözlerde kamaşmaya da sebep olarak görüş konforunu engellemektedir. Işık kaynaklarının miktarı, geliş açısı, konumu planlanarak ergonomik çalışma ortamı yaratılmalıdır. Doğal aydınlatmadan kaynaklı parlamaların önüne geçmek, sinema günleri gibi özel günlerde ortam atmosferini sağlamak için ise perdeler tercih edilmelidir.

Model 1'e ait z-kütüphane düzenlemesinde, giriş sirkülasyonuna paralel bir şekilde akıllı tahta ve bilgisayar masaları sıralanmıştır. Akıllı tahta girişte konumlandırılmıştır ve yanında kıyafet askısı bulunmaktadır. Tahtanın kullanımı anında kütüphaneye giren, kıyafetlerini asan bir kullanıcı görüşü engelleyecek, dikkati dağıtacaktır. Bunun dışında akılı tahtanın önünde kullanıcıların tahtayı izlemesi, toplanmaları için bir alan bırakılmamıştır. Bu durumda akıllı tahta tamamen işlevsiz kalmıştır. Altı adet bilgisayar masası da yan yana sıralanmıştır. Masa genişlikleri bilgisayar kullanırken not tutmaya, ders çalışmaya yetecek genişlikte değildir. Bilgisayar masalarının arka duvarında manzara fotoğrafı tercih edilmiştir ki bu fotoğraf dikkat dağıtıcı etkide bulunabilir (Şekil 4).
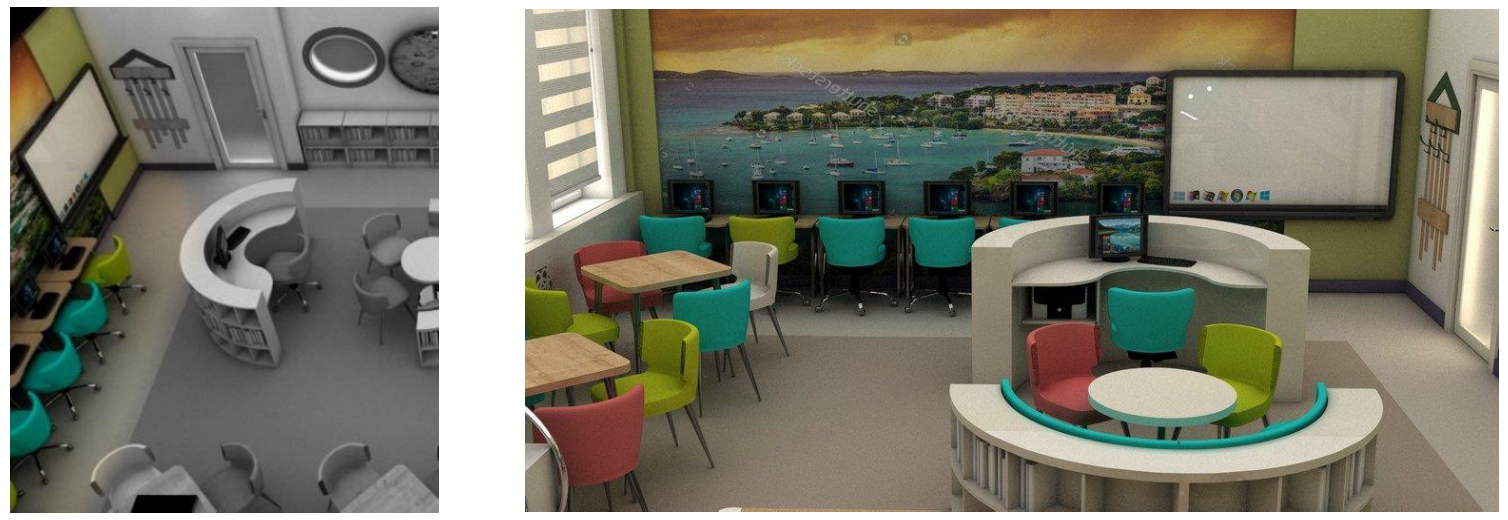

Şekil 4. Model 1'e ait dijital alanlara ait görseller (Görsel “Millî Eğitim Bakanlığı Z Kütüphane”-b kaynağından alınmış, 2. yazar tarafından düzenlenmiştir.)

Model 2'ye ait kütüphanede (Şekil 5), dijital alanlar grup çalışma alanlarıyla ilişkide konumlandırılmıştır, birbirini olumsuz etkilememektedir. Bilgisayar masaları dörderli gruplar halinde iki köşede konumlandırıımıştır. Akıllı tahta bir kitaplık ünitesi tasarımının içine oturtulmuştur. Tahtanın kullanıldığı anda çevrede kitap görselleri dikkat dağıtıcı olabilmektedir. Akıllı tahtanın önünde geniş bir alan bırakılarak yer minderleri yerleştirilmiştir. Bu sayede film günleri, ders sunumları gibi etkinlikler için esnek, rahat, eğlenceli bir alan sağlanmıştır. Bilgisayar alanının bir kısmı pencere önünde konumlandırılmıştır. Pencereden giren ışığın direkt olarak bilgisayar ekranına çarpması bilgisayar ekranında parlama gibi problemlere yol açabilir (Şekil 5). 

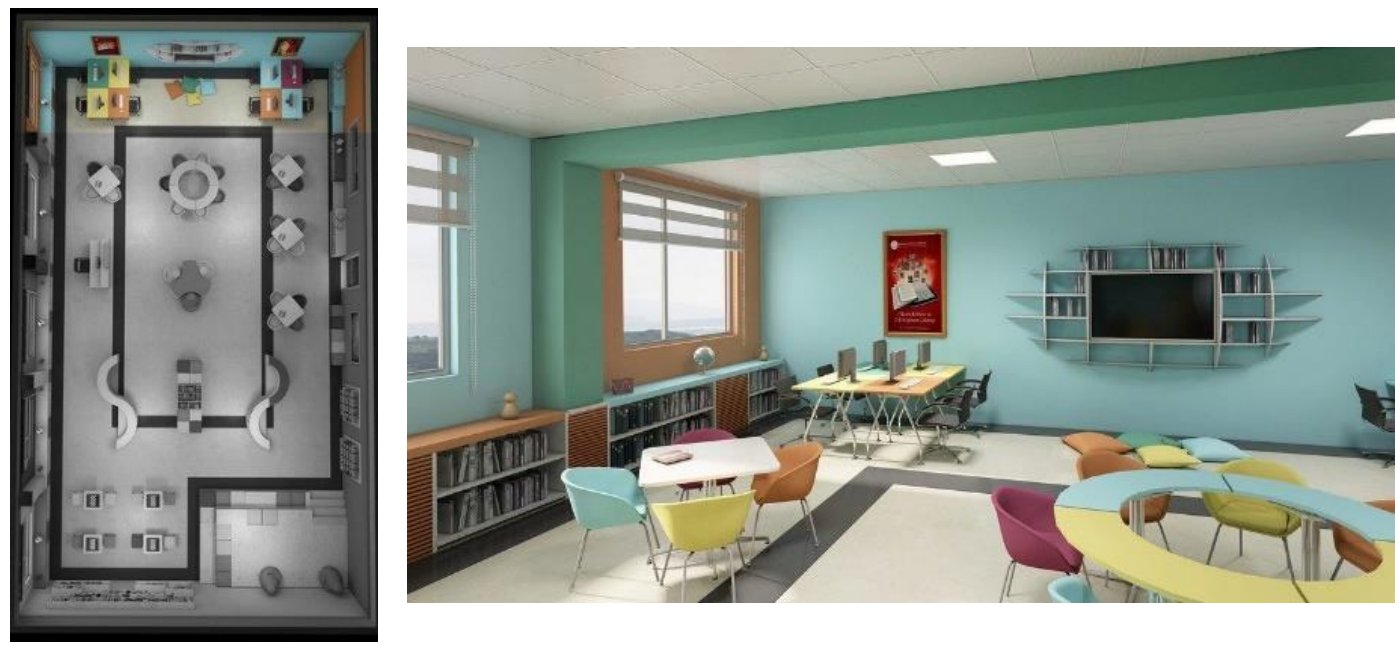

Şekil 5. Model 2’ye ait dijital alan görselleri (Millî Eğitim Bakanlığı Z Kütüphane).

Model 3'e ait z-kütüphanede akıllı tahta alanı girişte, kapının hemen yanında konumlandırılmıştır. Önünde dönüştürülebilir bir alan bulunmasına rağmen, giriş sirkülasyonunda olması tahtanın işlevsiz kaymasına yol açacaktır. Akıllı tahtanın altına yerleştirilen kitaplık da köşeli yapısı ile tehlike oluşturmaktadır ve konumu sebebi ile kullanımı zordur. Bilgisayar masalarının arka duvarı manzara fotoğrafı ve dünya haritası ile kaplanmıştır. Bilgisayar masalarında çalışma alanı için yeterli mesafe bırakılmamıştır. Bilgisayarlar pencerelerin karşı duvarında konumlandırıldığı için günışığının yoğun geldiği vakitlerde ekranlarda parlama yapabilir (Şekil 6).
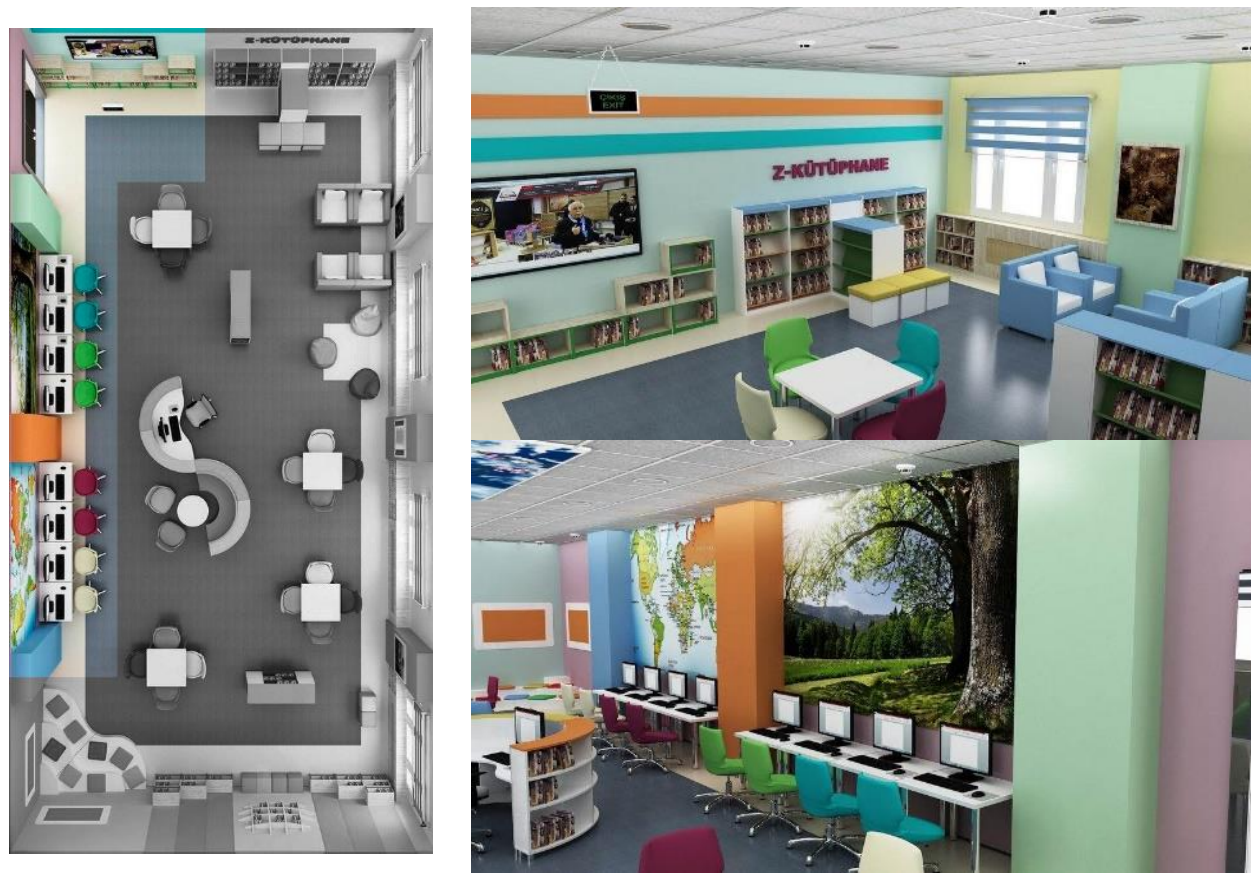

Şekil 6. Model 3’e ait dijital alan görselleri (Millî Eğitim Bakanlığı Z Kütüphane).

\subsubsection{Grup alanları}

Öğrencilerin kütüphaneyi kullanmada arkadaş etkisi düşünülerek Z-kütüphanelerde grup alanlarının işlevselliği büyük önem taşımaktadır. Grup alanları öğrencilere arkadaşlarıyla birlikte ders çalışma, kitap okuma, oyun oynama, sosyalleşme, takım çalışması yapma imkânı veren, aynı zamanda Zenginleştirilmiş Kütüphane (Z-Kütüphane) Kurulumu ve Donatımına Ilişkin Teknik Şartnamedeki 6.2.13. maddede yer alan iki adet ahşap satranç masası bulundurma şartını yerine getiren alandır ("Millî Eğitim Bakanlığı Z Kütüphane", 2019). Grup alanları işlevi nedeniyle ses düzeyinin diğer eylem alanlarına göre daha yüksek olduğu alanlardır. Bu alanda hem öğrenciler arası iletişimde sesin anlaşılır olması hem de alan içindeki ses düzeyinin diğer eylem alanlarındaki kullanıcıları etkilememesi için akustik düzenlemeler yapılmalıdır. Bu akustik düzenlemeler donatı ve zemin, tavan, duvar yüzeylerinde 
ses emici malzemeler kullanılması olabilir. Ayrıca grup alanlarının mekân içindeki dağılımı da akustik konforu sağlamada önemlidir.

İşleve yönelik mobilya olarak grup alanlarında kitap sergileme birimleri, çalışma masaları ve sandalyeleri, satranç masası ve sandalyeleri, rahat koltuklar bulundurulmalıdır. Masalar mekânın boyutsal yeterliliklerine göre 5 ve üzeri öğrencinin çalışmasına uygun ölçüde olabileceği gibi, alanda kullanılan masalar ihtiyaç anında birleştirilip grup etkinliklerine imkân veren düzenlemeler yapılarak hem işlevsellik desteklenir hem de alandan tasarruf sağlanabilir.

Model 1'de grup alanları sessiz alanla iç içe düzenlenmiştir. 4 kişilik masalar ve bir adet yarım daire formlu çalışma birimi kullanılmıştır. Bu masalar sessiz alan kullanıcıları tarafından da grup alanı kullanıcıları tarafından da kullanılmaktadır. Bu durum sessiz alanlarda gürültüye sebep olarak, bireysel çalışan kullanııılar için odaklanma sağlama açısından zorluk çıkarmaktadır. Kişi sayısının fazla olduğu etkinliklerde dört kişilik masalar birleştirilerek kullanılmaya uygundur. Ayrıca mekânda rahat oturma birimleri kullanılmıştır. Öğrenciler bu alanda arkadaşlarıyla birlikte verimli vakit geçirebilirler. Bu alanda ses emici bir malzeme olan halı da kullanılarak sıcak bir ortam sağlanmıştır. Kitap sergileme birimlerinde kitapların kapakları görünecek şekilde yerleştirilmiş bölümler olduğu görülmektedir. Fakat kullanılan kitap sergileme birimlerinde köşelerin yuvarlatılmamış olması öğrenciler için güvenlik sorunu oluşturmaktadır (Şekil 7).

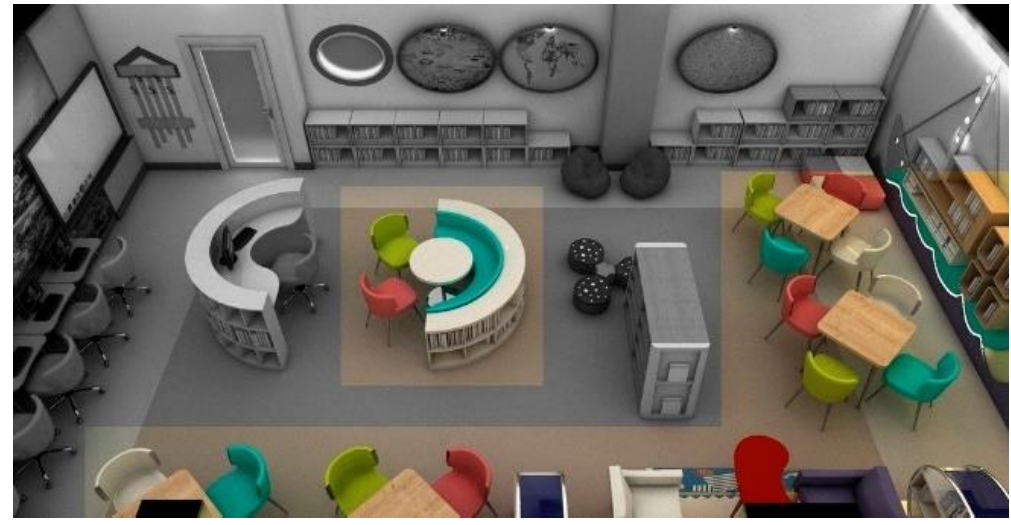

Şekil 7. Model 1'e ait grup alanlarını gösteren görsel (Millî Eğitim Bakanlığı Z Kütüphane).

Model 2'de grup alanında çeşitli grup çalışma birimlerine yer verilmiştir. Dört kişilik çalışma masaları kullanılmış, ihtiyaca göre 6 kişilik ya da daha küçük gruplar halinde kullanıma imkân veren bir çalışma birimi kullanılmıştır. Satranç oyunu için ise ayrıca bir alan düzenlenmiştir. Bu modelde de sessiz alan ve grup alanlarının çakıştığı görülmektedir. Sessiz alanlar için bireysel çalışma birimlerinin olmaması öğrencileri grup alanlarında çalışmaya yönlendirmektedir. Aynı zamanda bu çalışma birimlerinin giriş sirkülasyonu üzerinde olması öğrencilerin çalışma verimliliğini düşürebilir. Bu modelde grup alanlarında kitap sergileme birimi sadece duvarlarda ve pencere altlarında konumlandırılmıştır. Ortada görsel mahremiyeti sağlayan ve ses emici yüzeylere sahip birimlerin olmaması farklı grupların aynı anda çalışmasında kargaşaya sebep olabilir (Şekil 8).

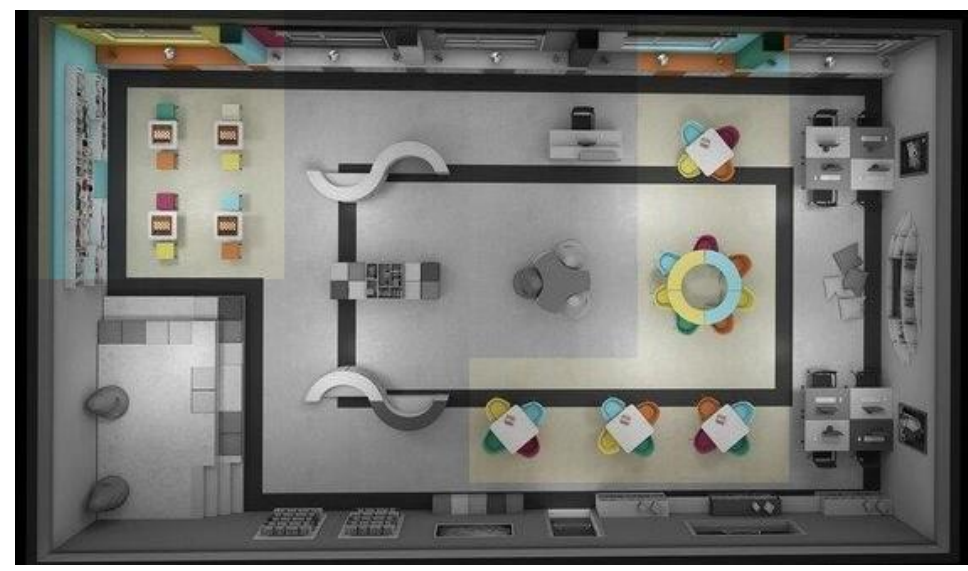

Şekil 8. Model 2'ye ait plan üzerinde grup alanlarının gösterimi (Millî Eğitim Bakanlığı Z Kütüphane). 
Model 3'te dörder kişilik çalışma masalarına, yarım daire formlu çalışma birimine, rahat oturma koltuklarına, puflara ve köşede renkli minderlerin olduğu bir platforma yer verilmiştir. Öğrenciler masa dışında koltuklarda ya da puflarda arkadaşlarıyla keyifli vakit geçirebilir, beraber okuma ve anlatma etkinlikleri yapabilir. Grup alanında kitap sergileme birimleri ortada ve pencere altlarında konumlandırılmıştır. Ortada bulunan üniteler sabitlenmemiş olduğunda en, boy ve genişlik oranı sebebiyle öğrencilerin çarpması ya da tırmanmaya çalışması durumunda devrilmeye yol açabilir. Dört kişilik tercih edilen masalar ihtiyaç halinde birleştirilip kullanılabilir. Bu alanda da sessiz alan için ayrılmış bireysel çalışma birimleri olmaması sebebiyle, masalar sessiz ve grup alanlarının kullanımı için ortaktır (Şekil 9).

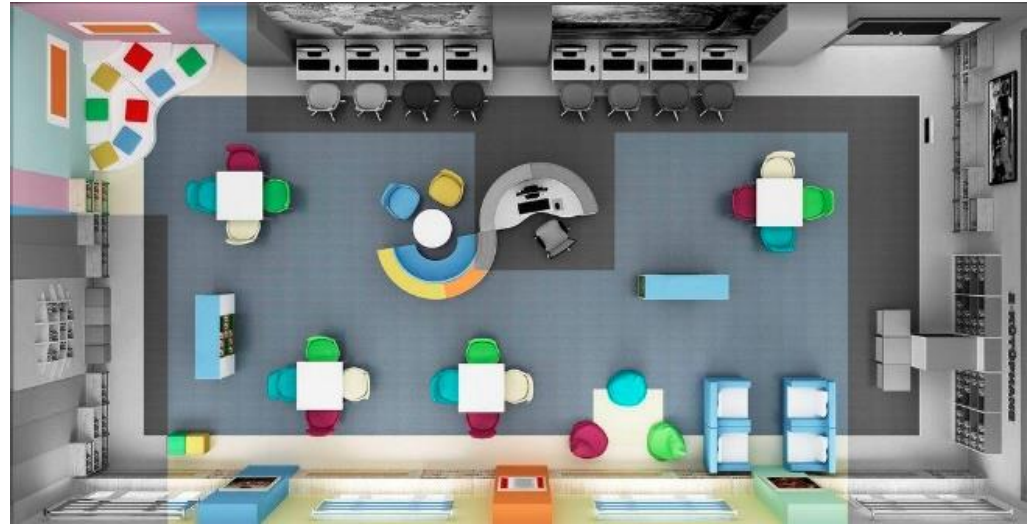

Şekil 9. Model 3’e ait plan üzerinde grup alanlarının gösterimi (Millî Eğitim Bakanlığı Z Kütüphane).

\subsubsection{Ofis alanı}

Z-kütüphanelerin amacını yerine getirmesi için sağlanması gereken en önemli alanlardan biri kütüphanecinin çalışma alanını içeren ofis alanıdır. Z-kütüphanede kütüphanecinin rolü;

- Z-kütüphanenin işleyişinden ve düzeninden sorumlu olmak,

- Z-kütüphanenin tanıtımını sağlamak,

- Okuma kültürünü geliştirmek ve Z-kütüphaneleri etkin kullanmayı sağlamak amacıyla çeşitli faaliyetler düzenlemek,

- Kütüphane kaynaklarının erişilebilir ve güncel tutulmasını sağlamak,

- Basılı kaynakların sınıflandırılmasını ve düzenlenmesini sağlamak,

- Kütüphane için yeni kaynakları oluşturmak ve seçmek,

- Okul idaresi ve öğretmenler ile iş birliği içinde çalışmalar yürütmek,

- Kitap kurdu öğrencileri belirleme ve ödüllendirme gibi okumaya teşvik amaçlı çalışmalar yapmak,

- Diğer okullardaki kütüphaneciler ile iletişime geçerek bilgi ve deneyim paylaşımı sağlamak olarak sıralanabilir (MEB Destek Hizmetleri Genel Müdürlüğü Eğitim Araçları ve Yayımlar Daire Başkanlığı, 2015).

Bu görevleri yerine getirmesi için kütüphaneciye sunulan çalışma alanının ergonomik yeterlilikleri ve işlevselliği önem taşımaktadır. Kütüphanecini masası bilgisayar kullanımının yanı sıra kütüphanecinin okul idaresi ya da öğretmenlerle çalışma yapabilmesi için yeterli boyutlarda olmalıdır. Masa kütüphane işleyişi için gerekli dokümanları ve malzemeleri depolamak, gerekli kaynakların da muhafaza edilmesini sağlamak için depolama birimlerine sahip olmalıdır. Aynı zamanda kullanıııların yazıcı, tarayıcı ve fotokopi hizmeti alması, aradığı bir kaynak hakkında bilgi danışması için gerekli birimler ilave edilmelidir. Ofis alanı kütüphane içinde girişte, kolay erişilebilir, kütüphaneyi gözleme olanağı veren bir konumda bulunmalıdır.

Model 1 ve 3'te ofis alanı yarım daire biçiminde tasarlanmış bir birimden oluşmaktadır. Bu birimlerde kütüphanecinin bilgisayar dışında çalışma yapabileceği gerekli alanlara yer verilmediği görülmektedir. Model 1'de ofis alanı kütüphanenin girişinde konumlandırılmıştır. Fakat kütüphanede diğer eylem 
alanlarına ters yönlendirilmiş olması sebebiyle kütüphanecinin kütüphaneyi rahatça gözlemesini kısıtlamaktadır. Model 3'te ise kütüphanenin ortasında konumlandırılmıştır. Kütüphanenin gözetimi kısmen sağlanmaktadır. Model 2'de ofis alanı giriş kapısının tam karşısında, kütüphaneyi tamamen gözetlemeye imkân veren bir alanda konumlandırılmıştır.

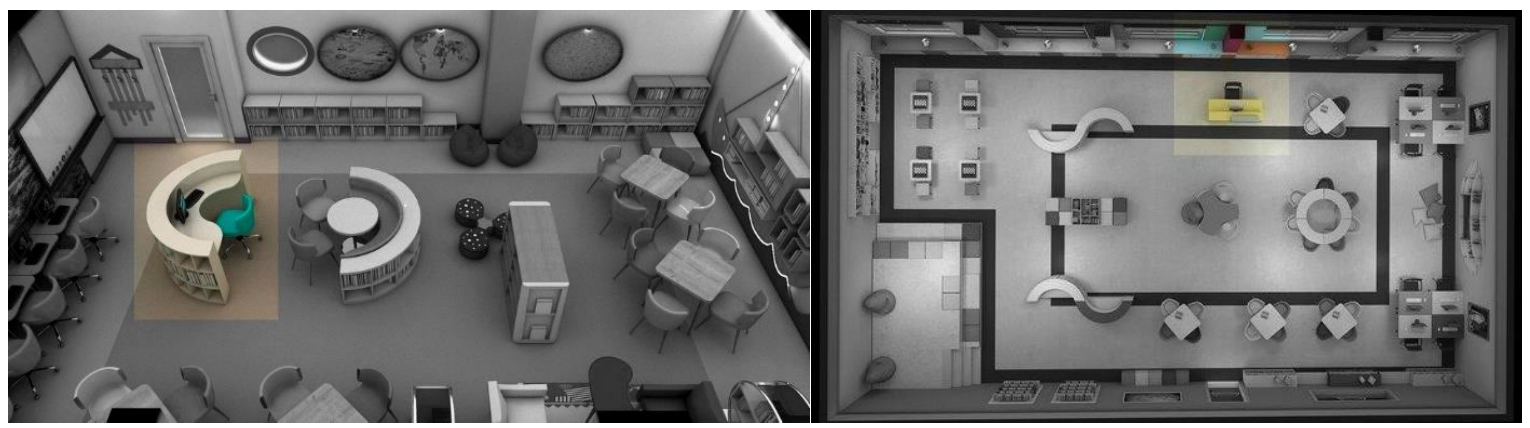

Şekil 10. Model 1 ve 3'e ait ofis alanlarının mekân görselleri üzerinde gösterimi (Millî Eğitim Bakanlığı Z Kütüphane).

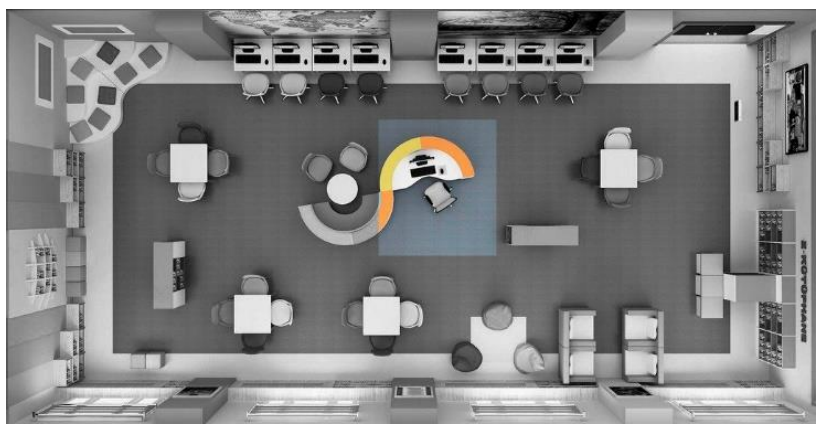

Şekil 11. Model 2'ye ait ofis alanının mekân görseli üzerinde gösterimi (Millî Eğitim Bakanlığı Z Kütüphane).

\section{Tartışma ve Sonuç}

Teknolojinin gelişmesiyle imkanların artması, yeni bilgi kaynak ve yöntemlerinin oluşması ve var olan bilgi kaynaklarına kolay ulaşılabilirlik eğitim sisteminin önemini ön plana çıkarmıştır. Eğitim sistemleri ülkelerin gelecek nesline hayat boyu öğrenme yeteneğini kazandırma, bilgiye ulaşma ve kullanma yollarını öğretmektedir. Bu amaçlar doğrultusunda okul kütüphaneleri eğitim sisteminin en büyük yardımcılarından biridir. Okul kütüphaneleri birçok öğrenci için kütüphane kavramıyla ilk karşılaşılan yerdir.

Türkiye'de yeni bilgiye ulaşma yöntemlerini öğrenciye öğretebilmek, öğrencilere ilgi çekici, keyifle vakit geçireceği hem bilgiyle buluşup hem sosyalleşeceği bir kütüphane oluşturmak amacıyla MEB Zenginleştirilmiş Kütüphane projesini hayata geçirmiştir. Z-Kütüphanelerle ilgili ilkeler bu kütüphanelerin mekânsal tasarım özellikleriyle ön plana çıktığını göstermektedir. İyi bir iç mekân tasarımıyla öğrencilerin ilgisini çekerek kütüphane kullanımını arttırmayı amaçlayan bu projede tasarım ile işlevselliğin sağlanması sürdürülebilir bir kütüphane kullanımı açısından önem kazanmaktadır. ZKütüphane projesinde iç mekân tasarımı, web sitesi üzerinden paylaşılan modeller örnek alınarak, yapılan ihalelerle yüklenici firmalar tarafından gerçekleştirilmektedir. Bu firmalarda iç mimarların görevlendirilmemiş olması ve iç mimarların projelendirme aşamasında bir şart olarak projeye dahil edilmemeleri ile yapılan z-kütüphane mekanlarında işlevselliğin sağlanması konusunda aksaklıklar yaşandığı tespit edilmiştir.

Z-Kütüphanede eylem alanları sessiz alan, dijital alan, grup alanları ve ofis alanı olmak üzere dört temel alana ayrılmaktadır. Her eylem alanının işlevi farklı olduğu gibi ihtiyaçları da farklılıklar göstermektedir. Z-Kütüphanelerde eylem alanları örnek modeller üzerinden işlevsellik bağlamında incelendiğinde aşağıdaki çizelgede ifade edilen sonuçlara ulaşılmıştır. 
Çizelge 2: Z-Kütüphanelerde eylem alanlarının örnek modeller üzerinden incelenmesi sonucu yapılan tespitler

\begin{tabular}{|c|c|c|c|}
\hline & Model-1 & Model-2 & Model-3 \\
\hline Sessiz Alan & $\begin{array}{l}\text {-Çeşitli bireysel oturma } \\
\text { birimlerine yer verilmiştir. } \\
-4 \text { kişilik çalışma masaları } \\
\text { kullanılmıştır. } \\
\text {-Tek kişilik çalışma birimleri } \\
\text { bulunmamaktadır. } \\
\text {-Görsel mahremiyet sağlayıcı } \\
\text { donatılara yer verilmemiştir. } \\
\text {-Yanlış konumlandırmadan ötürü } \\
\text { erişim sağlanamayan kitaplıklar } \\
\text { mevcuttur. } \\
\text {-Eğlenceli kitaplık tasarımına yer } \\
\text { verilmiştir. } \\
\text {-Köşeli mobilyalar kullanılarak } \\
\text { güvenlik ihlal edilmiştir. } \\
\text {-Halı kullanılmıştır. } \\
\text {-Eylem alanlarının çakışmasından } \\
\text { ötürü akustik problemler } \\
\text { öngörülmektedir. }\end{array}$ & 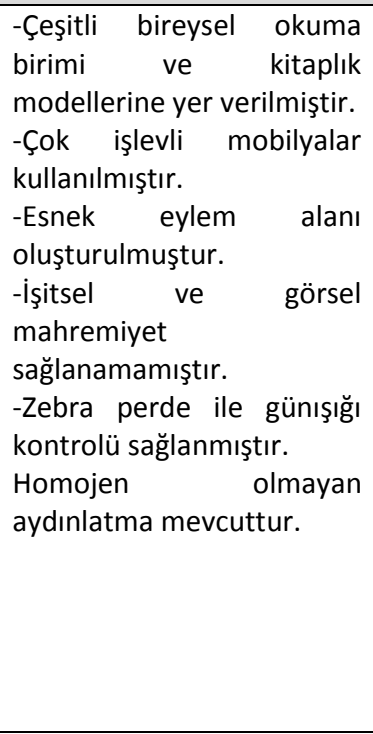 & $\begin{array}{l}\text {-Çeşitli bireysel okuma birimi ve } \\
\text { kitaplık modellerine yer verilmiştir. } \\
\text {-Yanlış konumlandırmadan ötürü } \\
\text { işlevini kaybetmiş kitaplık } \\
\text { mevcuttur. } \\
\text {-Yanlış konumlandırmadan ötürü } \\
\text { erişim sağlanamayan duvar panosu } \\
\text { mevcuttur. } \\
\text {-Devrilme riski taşıyan mobilyalar } \\
\text { bulunmaktadır. } \\
\text {-Eylem alanlarının çakışmasından } \\
\text { ötürü akustik problemler } \\
\text { öngörülmektedir. } \\
\text {-Zebra perde ile günışığı kontrolü } \\
\text { sağlanmıştır. } \\
\text {-Gergi tavan kullanılımıştır. } \\
\text {-Duvarda İstiklal Marşı ve Çanakkale } \\
\text { Savaşı görsellerine yer verilmiştir. }\end{array}$ \\
\hline Dijital Alan & $\begin{array}{l}\text {-Akıllı tahta sirkülasyon alanında } \\
\text { kalması sebebiyle işlevini } \\
\text { kaybetmiştir. } \\
\text {-Bilgisayar masaları not tutmaya } \\
\text { elverişli genişliklere sahip değildir. } \\
\text { Duvarda dikkat dağıtıcı manzara } \\
\text { fotoğrafı kullanılmıştır. }\end{array}$ & $\begin{array}{l}\text {-Dijital alan mekanda iyi } \\
\text { konumlandırılmıştır. } \\
\text {-Esnek akıllı tahta alanı } \\
\text { oluşturulmuştur. } \\
\text {-Parlama problemine sebep } \\
\text { olacak bilgisayar } \\
\text { konumlandırmaları } \\
\text { mevcuttur. }\end{array}$ & $\begin{array}{l}\text {-Akıllı tahta sirkülasyon alanında } \\
\text { kalması sebebiyle işlevini } \\
\text { kaybetmiştir. } \\
\text {-Köşeli mobilyalar ve raflar } \\
\text { kullanılarak güvenlik ihlal edilmiştir. } \\
\text {-Bilgisayar masaları not tutmaya } \\
\text { elverişli genişliklere sahip değildir. } \\
\text {-Parlama problemine sebep olacak } \\
\text { bilgisayar konumlandırmaları } \\
\text { mevcuttur. } \\
\text {-Duvarda manzara fotoğrafı ve } \\
\text { dünya haritası görseline yer } \\
\text { verilmiştir. }\end{array}$ \\
\hline Grup Alanları & $\begin{array}{l}\text {-Sessiz alanla iç içe } \\
\text { konumlandırımıştır. } \\
\text {-Çeşitli çalışma birimlerine yer } \\
\text { verilmiştir. } \\
\text {-Birleştirilmeye uygun masalar } \\
\text { kullanılmıstır. } \\
\text {-Rahat oturma alanları mevcuttur. } \\
\text {-Farklı kitap sergileme birimlerine } \\
\text { yer verilmiştir. } \\
\text {-Eylem alanlarının çakışmasından } \\
\text { ötürü akustik problemler } \\
\text { öngörülmektedir. } \\
\text {-Köşeli mobilyalar kullanılarak } \\
\text { güvenlik ihlal edilmiştir. }\end{array}$ & $\begin{array}{l}\text {-Özel ayrılabilir grup masası } \\
\text { bulunmaktadır. } \\
\text {-Özel satranç alanı } \\
\text { oluşturulmuştur. } \\
\text {-Eylem alanlarının } \\
\text { çakışmasından ötürü } \\
\text { akustik problemler } \\
\text { öngörülmektedir. } \\
\text {-Çalışma alanları giriş } \\
\text { sirkülasyonu üzerinde } \\
\text { konumlandırılarak olmayan } \\
\text { ergonomik } \\
\text { koşullar oluşturulmuştur. } \\
\text {-Görsel mahremiyet } \\
\text { sağlayıcı donatılara yer } \\
\text { verilmemiştir. }\end{array}$ & $\begin{array}{l}\text {-Farklı çalışma ve oturma } \\
\text { birimlerine yer verilmiştir. } \\
\text {-Birleştirilmeye uygun masalar } \\
\text { kullanılmaktadır. } \\
\text {-Devrilme riski taşıyan mobilyalar } \\
\text { bulunmaktadır. } \\
\text {-Eylem alanlarını çakışmasından } \\
\text { ötürü akustik problemler } \\
\text { öngörülmektedir. }\end{array}$ \\
\hline Ofis Alanı & $\begin{array}{ll}\text {-Mekânda } & \text { yanlış } \\
\text { konumlandırımıştır. } & \\
\text {-Kütüphanecinin çalışma } & \text { alanı } \\
\text { boyutları yetersizdir. } & \end{array}$ & $\begin{array}{ll}\text {-Mekânda } & \text { doğru } \\
\text { konumlandırılmıştır. } \\
\text {-Kütüphanecinin çalışma } \\
\text { alanı boyutları kısmen } \\
\text { yetersizdir. }\end{array}$ & $\begin{array}{ll}\text {-Mekânda } & \text { yanlış } \\
\text { konumlandırılmıştır. } & \\
\text {-Kütüphanecinin çalışma } & \text { alanı } \\
\text { boyutları yetersizdir. } & \end{array}$ \\
\hline
\end{tabular}

Bu sonuçlar, yüklenici firmalar için örnek olması gereken modellerin fazlasıyla eksiklik içerdiğini ve projenin iç mimarlar eşliğinde yeniden ele alınması gerekliliğini de ortaya koymaktadır.

\section{Teşekkür ve Bilgi Notu}

Bu makale, Kocaeli Üniversitesi Sosyal Bilimler Enstitüsü İç Mimarlık Ana Sanat Dalı'nda tamamlanan "Çocuk İçin Mekân Tasarımı" adlı ders kapsamında üretilmiştir. Makalede, ulusal ve uluslararası araştırma ve yayın etiğine uyulmuştur. Çalışmada Etik Kurul izni gerekmemiştir. 
Yazar Katkısı ve Çıkar Çatışması Beyan Bilgisi

Makalede tüm yazarlar aynı oranda katkıda bulunmuştur. Herhangi bir çıkar çatışması bulunmamaktadır.

\section{Kaynakça}

Baran, G. (2011). Çocuk Gelişimine Giriş, N. Aral ve G. Baran (Ed.), Çocuk Gelişimi, İstanbul: YaPa Yayınları.

Bayram, Z. (2011). İşlevsellik ve Esneklik Bağlamında Konut İç Mekân Tasarımında Mobilya Kullanımı (yüksek lisans tezi). YÖK tez merkezinden edinilmiştir (296675).

Doğan, Y. (2007). İlköğretim çağındaki $10-14$ yaş grubu öğrencilerinin gelişim özellikleri. Uludağ Üniversitesi Fen-Edebiyat Fakültesi Sosyal Bilimler Dergisi, 8(13), 155-187.

Gürbüz, M. (2013). IFLA/UNESCO okul kütüphanesi rehberi. Türk Kütüphaneciliği, 27(3), 544-562.

Hashempour, L. (2015). Okul kütüphanelerinde renk etkileri ve önemi. Milli Eğitim Dergisi, 45(208), 5160.

Hasol, D. (2020). Ansiklopedik Mimarlık Sözlüğü (18. b.). İstanbul: YEM Yayın.

Önal, H. İ. (2015). Okul kütüphaneleriyle öğrencilerin 21. yüzyıla hazırlanması. Millî Eğitim Dergisi, 45(208), 233-248.

IFLA Okul Kütüphaneleri Bölümü Daimî Komitesi. (2002). IFLA/UNESCO Okul Kütüphanesi Rehberi. Erişim Adresi: https://www.ifla.org/files/assets/school-libraries-resourcecenters/publications/school-library-guidelines/school-library-guidelines-tr.pdf

Küçükcan, B. (2015). Okul kütüphanelerinde mekân tasarımı. Milli Eğitim Dergisi, 208, 218-232. Erişim adresi: https://dergipark.org.tr/tr/pub/milliegitim/issue/36142/406096

Millî Eğitim Bakanlığı Destek Hizmetleri Genel Müdürlüğü Eğitim Araçları ve Yayımlar Daire Başkanlığı. (2015). Okuma kültürü ve Z-Kütüphane çalıştay sonuç raporu. Erişim adresi: https://dergipark.org.tr/en/download/issue-file/11234

Millî Eğitim Bakanlığı $Z$ Kütüphane. (t.y.).-a, Hakkımızda. Erişim adresi: https://zkutuphane.meb.gov.tr/Home/Hakkimizda

Millî Eğitim Bakanlığı Z Kütüphane. (t.y.).-b, Ortaokul modeli. Erişim adresi: https://zkutuphane.meb.gov.tr/Home/ZkutuphaneModellerDetayi/9

Millî Eğitim Bakanlığı Z Kütüphane. (2019). Zenginleştirilmiş kütüphane (z-kütüphane) kurulumu ve donatımına ilişkin teknik şartname. Erişim adresi: http://zkutuphane.meb.gov.tr/Home/ZkutuphaneDokumanlarDetayi/9

Miner94. (2009, 17 Temmuz). Color in school libraries [Blog yazısı]. Erişim Adresi: http://miner94.blogspot.com.tr/2009/07/color-in-school-libraries.html

Okul Kütüphanecileri Derneği. (t.y.). Fiziki ilke ve standartlar. Erişim Adresi: http://okulkutuphanecileri.org/index.php/tr/sts/fis

Türkiye Cumhuriyeti Cumhurbaşkanlığı Strateji ve Bütçe Başkanlığı. (2019, Temmuz). On birinci kalkınma planı. Erişim adresi: https://www.sbb.gov.tr/wpcontent/uploads/2019/07/OnbirinciKalkinmaPlani.pdf 